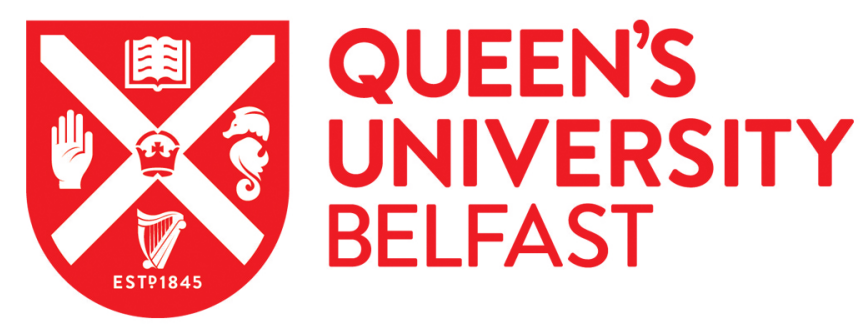

\title{
Sowing the seeds of subsidiary influence: Social navigating and political maneuvering of subsidiary actors
}

Conroy, K. M., Collings, D. G., \& Clancy , J. (2019). Sowing the seeds of subsidiary influence: Social navigating and political maneuvering of subsidiary actors. Global Strategy Journal , 9(4), 502-526.

https://doi.org/10.1002/gsj.1323

\section{Published in:}

Global Strategy Journal

\section{Document Version:}

Peer reviewed version

Queen's University Belfast - Research Portal:

Link to publication record in Queen's University Belfast Research Portal

\section{General rights}

Copyright for the publications made accessible via the Queen's University Belfast Research Portal is retained by the author(s) and / or other copyright owners and it is a condition of accessing these publications that users recognise and abide by the legal requirements associated with these rights.

Take down policy

The Research Portal is Queen's institutional repository that provides access to Queen's research output. Every effort has been made to ensure that content in the Research Portal does not infringe any person's rights, or applicable UK laws. If you discover content in the Research Portal that you believe breaches copyright or violates any law, please contact openaccess@qub.ac.uk. 


\title{
Sowing the seeds of subsidiary influence: Social navigating and political manoeuvring of subsidiary actors
}

\author{
Dr. Kieran M. Conroy \\ Lecturer in International Management \\ Queen's Management School, Queen's University Belfast, \\ Riddel Hall, 185 Stranmillis Road, Belfast, Northern \\ Ireland, BT9 5EE, UK. \\ Email.k.conroy@qub.ac.uk \\ Professor David G. Collings (Corresponding Author) \\ Professor of Human Resource Management \\ Leadership \& Talent Institute, DCU Business School, Dublin City University, \\ Glasnevin, Dublin 9, Ireland. \\ Email. david.collings@dcu.ie \\ Dr. Johanna Clancy \\ Lecturer in Business Enterprise \\ J. E. Cairnes School of Business \& Economics, \\ National University of Ireland, Galway, Ireland. \\ Email. johanna.clancy@,nuigalway.ie
}

Keywords: Subsidiary Influence; Micro-politics; Social and Political skill; Mandate Repositioning

\section{Research summary}

This paper emphasises the social and political dimensions of subsidiary influence in strategically repositioning the subsidiary's mandate. The specific skills subsidiary actors deploy in attempting to influence corporate headquarters have largely been neglected in existing literature. Drawing from a micro-political perspective, we provide a more nuanced, fine-grained understanding of subsidiary influence by illuminating how influence is augmented and enriched through the concomitant effects of subsidiary actors' social and political skills. Using a multiple case study analysis, drawing on qualitative interviews, we illustrate how subsidiary actors' social skills are used to continuously create, maintain and develop spaces of social engagement with corporate decision makers, whereas political skill involves the ability to leverage social spaces by developing specific influence tactics such as targeting, showcasing and framing.

This article has been accepted for publication and undergone full peer review but has not been through the copyediting, typesetting, pagination and proofreading process, which may lead to differences between this version and the Version of Record. Please cite this article as doi: $10.1002 / \mathrm{gsj} .1323$ 


\section{Managerial summary}

Subsidiaries of multinational companies play an increasingly dominant role in the global business environment. The role of the individual subsidiary actor in influencing corporate management is crucial to the development of the subsidiary mandate. Despite this, very little is known about the micro-level skills that individual subsidiary actors draw upon to influence the development of their mandates. This paper explores how subsidiary actors channel key social and political skills in strategically repositioning their mandates within the multinational enterprise. We find that subsidiary actors may use their social skill to establish increased interaction and communication with key corporate decision makers, whereas political skill is used to develop a variety of influence

tactics. 


\section{INTRODUCTION}

Multinational enterprises (MNEs) are characterised by continually shifting structures, often driven by global and local conflicts of power between corporate headquarters (HQ) and foreign subsidiaries (Ambos, Asakawa and Ambos, 2011; Clegg, Geppert and Hollinshead, 2018; Geppert, Becker-Ritterspach and Mudambi, 2016). The corporate HQ's aspiration to exert greater control and coordination is continuously countered or challenged by the subsidiary's interest in achieving auxiliary levels of autonomy and influence (Dorrenbacher and Gammelgaard, 2016; Forsgren, Holm and Johanson, 2005; Narula, 2014). Contemporary changes in MNE structural design, from hierarchical to network-based architectures, create opportunities and challenges for a subsidiary's mandate, which manifest in investment or relocation decisions (Andersson, Forsgren and Holm, 2007). This is a strategic problem for subsidiaries, in that subsidiary actors that are not seeking to consistently develop influence over their corporate HQ during these changes may risk mandate divestment or strategic isolation (Monteiro, Arvidsson and Birkinshaw, 2008). Despite extant research acknowledging that the position of the subsidiary is largely dependent on the influence it cultivates over corporate HQ (Asakawa et al. 2017; Conroy and Collings, 2016; Garcia-Pont, Canales and Noboa, 2009; Yamin and Andersson, 2011) our understanding of the specific mechanisms through which key actors in the subsidiary gain and maintain influence over the corporate HQ during mandate change remains limited. As such, greater consideration of subsidiary influence as a continuous activity that is frequently contested over time, rather than incidentally established in defined periods of bargaining or negotiation is an important focus (Dorrenbacher and Gammelgaard, 2006; Najafi-Tavani, Giroud and Andersson, 2014).

Taking the perspective of the MNE as a political arena captures a central problem for subsidiaries, in that any influence the subsidiary develops is continuously in flux and not easily sustained, as other powerful and influential actors attempt to cultivate favourable positions of 
their own (Clegg et al. 2018). Recent research has argued that the architectural shift from hierarchical to a network-based MNE has set the scene for a 'high-stakes' political contestation between corporate HQ and foreign subsidiaries in a bid to preserve or develop influence (Egelhoff and Wolf, 2017; Levy and Reiche, 2017). More specifically, MNEs are populated by individual actors who have diverse political objectives, formed through a multitude of social interactions (Harvey and Novecevic, 2004; Kostova and Roth, 2003; Morgan and Kristensen, 2006). In this sense, the concept of subsidiary influence has remained largely 'face-less' in explaining how significant transitional exchanges in the corporate HQ-subsidiary relationship represent a global political game, dominated by ongoing micro-level interactions from key actors at the subsidiary level (O’Brien et al. 2018; Forsgren et al. 2005; Kristensen and Zeitlin, 2005). In particular, shifting structures in the form of mandate change create 'contested social spaces' within the MNE leading to increasingly intense social and political interactions between powerful actors seeking to establish greater influence (Dorrenbacher and Gammelgaard, 2016; Geppert and Dorrenbacher, 2014). These social and political interactions create further opportunities for individual actors to leverage and channel particular skills within changing social hierarchies over time (Cullen, Gerbasi, and Chrobot-Mason, 2015; Levy and Reiche, 2017). We argue that in order to create a more nuanced and granular explanation of subsidiary influence, independent from the formal resources the subsidiary possesses and structures it operates in, we need to explore the social and political undertakings of key subsidiary actors in the context of mandate change. Drawing on the micro-political lens of the corporate HQ-subsidiary relationship (Dorrenbacher and Gammelgaard, 2006, 2016; Geppert and Dorrenbacher, 2014; Kristensen and Zeitlin, 2005; Morgan and Kristensen, 2006), we explore how subsidiary actors use their social and political skills to augment and enrich subsidiary influence in the context of mandate change?

The main contribution of our study lies in identifying the specific mechanisms through which key actors in the subsidiary gain and maintain influence over the corporate HQ during mandate 
change. Our findings illuminate how the concomitant effects of social skill and political skill are important to augment and enrich influence in the context of strategically repositioning the subsidiary's mandate within the MNE. Subsidiary actors leverage social skill in order to continuously create, maintain and develop spaces of social engagement with key decision makers, whereas political skill enables the leveraging of social spaces by developing specific influence tactics. A major contribution of our study comes in the form of a typology of subsidiary actor influence roles that explicates how various roles are defined by the degree of social navigating and political manoeuvring that subsidiary actors undertake. We provide a more nuanced microlevel understanding of subsidiary influence, by illuminating the importance of the social and political dimensions of subsidiary influence (Kostova and Roth, 2003; Levy and Reiche, 2017). Drawing on the micro-political perspective of the MNE we answer calls to explore how influence is augmented and enriched in the socio-political dynamics that are ground in microlevel interactions between key actors in the corporate HQ-subsidiary relationship (Clegg et al. 2018; Dorrenbacher and Gammelgaard, 2016; Geppert and Dorrenbacher, 2014). The paper is structured as follows. After detailing the theoretical background, we introduce the qualitative nature of the methodology. Our findings are subsequently presented before a conclusion of the main contributions of the research.

\section{SUBSIDIARY INFLUENCE FOR MANDATE CHANGE}

Traditionally, the MNE hierarchy is conceptualised with power as a centralised concept, in that corporate HQ controls subsidiary operations through the allocation of formal resources or implementation of normative integration mechanisms (Foss, Foss and Nell, 2012; Kostova, Marano and Tallman, 2016). The networked perspective of the MNE focuses on the increasingly differentiated nature of subsidiary operations and their ability to independently acquire and develop mandates (Andersson et al. 2007; Narula, 2014). In this networked context, influence is a reciprocal process as the subsidiary is not only affected by corporate HQ, but it in turn also 
affects the behaviour of corporate decision makers (Forsgren et al. 2005; Pla-Barber, Villar and Madhok, 2017). The position of the subsidiary in particular is largely determined by the role they enact or the legal mandate they possess from corporate HQ, with more significant mandates translating to greater subsidiary influence (Bouquet and Birkinshaw, 2008a). Mandates may be defined as tasks assigned to subsidiaries, or responsibilities acquired independently, as the corporate HQ creates a division of labour and controls the degree of decision making autonomy each subsidiary possesses (Birkinshaw, 1996; Cantwell and Mudambi, 2005). These tasks or responsibilities may be related to a product, market or value-added scope in existing or new functions for the subsidiary (Dorrenbacher and Gammelgaard, 2006). Extant research details the various types of subsidiary mandates or 'charters' (Bouquet and Birkinshaw, 2008a; Cantwell and Mudambi, 2005; Galunic and Eisenhardt, 1996) and more recently explores how subsidiaries develop or manage the evolution of their mandates (Andersson et al. 2007; Cavanagh et al. 2017; Dorrenbacher and Gammelgaard, 2016; Mudambi, Pedersen and Andersson, 2014; Tippmann et al. 2018). All of these studies recognise that subsidiaries have to be cognisant of the control and power corporate HQ has over their ability to influence and 'upgrade' to a more advanced mandate than initially allocated (Asakawa et al. 2017; Burger et al. 2017; Garcia-Pont et al. 2009).

MNEs may display elements of both hierarchical and network-based structures, particularly during structural change and this creates further complexities for subsidiaries in gaining and maintaining influence (Ambos et al. 2011; Clegg et al. 2018; Egelhoff and Wolf, 2017; Forsgren et al. 2005). As such, we argue that subsidiary mandates are more fluid than current theorising acknowledges. They can be developed or divested depending on internal and external changes that affect the overall corporate structure (Birkinshaw and Hood, 1998; Bouquet and Birkinshaw, 2008a), such as responses to changing customer preferences, changes in CEO or acquisitions. Despite these changes, the challenge for the subsidiary is that it is expected to maintain its mandate in accordance with the corporate strategy, as corporate executives hold the overall 
power (Asakawa et al. 2017; Yamin and Andersson, 2011). As such, a strategic problem for subsidiaries involves the maintenance of an influential relationship with corporate HQ in the context of growing complexity throughout the MNE network, which creates significant variability in their mandates (Conroy and Collings, 2016). Extant research has largely failed to address the ways in which subsidiary actors continuously negotiate and improve their often ambiguous and fluctuating mandate positions (Alfoldi, McGaughey and Clegg 2017; Burger et al. 2017). The possession of a specific mandate or resource may ensure a prominent role for the subsidiary but certainly will not guarantee influence over time, given that the interests of key corporate actors and MNE structures are continuously changing (Levy and Reiche, 2017). As such, we define subsidiary influence broadly as the ability to affect the strategic decision making of corporate HQ.

A major criticism of current research on subsidiary influence is that it fails to consider how the micro-level interactions that produce interconnected relationships between key actors create more nuanced and informal forms of subsidiary influence (Forsgren et al. 2005; Geppert and Dorrenbacher, 2014). Micro-level interactions in a networked structure may be important for informing increasingly distanced and rationally bounded corporate executives of the activities the subsidiary actors are involved in (Ciabuschi, Forsgren and Martin, 2011; Menz, Kunisch and Collis, 2015). Subsidiaries may need to consistently convince corporate HQ of the legitimacy of their activities as the more knowledge corporate executives have about these activities the more likely the subsidiary will be perceived as transparent and trustworthy (Asakawa et al. 2017; Conroy and Collings, 2016). As such, keeping corporate HQ informed is clearly an important part of a subsidiary's strategy, but knowing when to inform, who specifically to inform and how exactly to do this are key characteristics of any influence the subsidiary wishes to maintain (Geppert and Dorrenbacher, 2014). 
Despite these observations, research on subsidiary influence has yet to consider how the daily interactions that take place between key actors at the corporate HQ-subsidiary interface provide a micro-level foundation for enhancing subsidiary influence. The next section introduces the micro-political perspective of the MNE as a lens to explore the more nuanced and fine-grained facets of subsidiary influence.

\section{Subsidiary micro-politics}

From a micro-political perspective, the MNE can be viewed as a political arena (Clegg et al.2018; Morgan and Kristensen, 2006) in which micro-political interactions between key actors have the ability to create, shape and change organisational structures (Conroy, Collings and Clancy, 2017). Micro-politics are defined as the portfolio of daily tactics in which influence is built up and applied in order to extend room for further manoeuvring (Pfeffer, 1978; Winkler, 2010). Micropolitics are therefore an important means of exerting influence over others, or influence in action', through spaces of contestation or negotiation, and the individual actors involved are ‘micro-politicians' or 'influencers' (Mintzberg, 1983).

Mandates changes, in terms of gains or losses, may be portrayed as critical 'micro-events' in the larger context of shifting MNE structures, triggering micro-political strategising, but this issue has received little attention in international strategy literature (Becker-Ritterspach et al. 2016). Equally, studies on the political perspective of the MNE call for further research at the microlevel by exploring the influence tactics individual actors use to develop the subsidiary's mandate (Geppert and Dorrenbacher, 2014). Subsidiary actor's intentions are not always directly aligned to the corporate agenda and individuals may have their own political objectives (Geppert et al. 2016). It is important to note that micro-political interactions do not only take place in formal dyadic relationships in a hierarchy, but are more prevalent within the informal daily interactions between individuals, allowing greater room for manoeuvre to pursue personal agendas (Winkler, 
2010). As such, the micro-political perspective argues that 'everyone is influencing everyone else' regardless of the formal roles and resources they possess in the organisation (Kipnis, Schmidt and Wilkinson, 1980).

Using micro-politics as a lens to investigate subsidiary influence allows us to develop a muchneeded understanding of how key actors' skills and activities influence the development of the subsidiary's mandate (Dorrenbacher and Gammelgaard, 2016). Specifically, the micro-level activities by subsidiary actors in attempting to enhance their influence over corporate HQ require significant social and political undertakings (Clegg et al. 2018; Geppert and Dorrenbacher, 2014).

\section{Social and political interactions}

Subsidiaries may not necessarily need to possess valuable resources to establish influence, but they need to control, or have access to, the social relationships that provide these resources (Dorrenbacher and Gammelgaard, 2016; Forsgren et al. 2005; Kostova and Roth, 2003). Structural changes within the MNE may provide subsidiary actors with the opportunity to create important 'social spaces' for relationship building (Geppert and Dorrenbacher, 2014). Relationship building in this manner is an important part of micro-politics and often manifests in the form of establishing coalitions with key decision makers (Winkler, 2010). Developing an extensive interpersonal network of social relations in order to gather information and mobilize support when needed is an important antecedent to establishing influence (Ammeter et al. 2002). That political actors at the subsidiary level 'may interact readily and directly' with key decision makers is well recognised (Kostova and Roth, 2003: 305) but this perspective fails to address 'how' key subsidiary actors informally create or operate in social spaces on a regular basis (Ammeter et al. 2002). These social spaces are found in the relational structures between and among individual actors, but built through regular and recurrent social interactions (Baron and Markman, 2000; La Due Lake and Huckfeldt, 1998). Despite this, a major criticism of the micro- 
political perspective is that it largely fails to consider how exactly key actors cultivate social spaces for greater levels of social interaction that provide the foundation for further political manoeuvring.

Studies on subsidiary influence commonly assume that 'managers of subsidiaries are better positioned than anyone to anticipate critical needs of corporate HQ' (Molloy and Delany, 1998: 12). This perspective overlooks the importance of the 'social skill' of individual actors as a way to firstly 'gain access' to decision makers (Baron and Markman, 2000). Social skill is important for understanding how patterns of social interaction are created and leveraged, as it involves the purposeful development of recurrent patterns in social relationships (Granovetter, 1985). As such, social skill involves the ability to create social spaces, which are an important prerequisite to creating and developing social interactions (Baron and Markman, 2000). Extensive, efficacious and quality interactions may lead to a higher chance of subsidiary actors developing personal relations with corporate executives (Kostova and Roth, 2003). Social skill may be particularly relevant in the context of larger structural changes, and the flexibility to adapt to changes in the social hierarchy that lead to the development of new networks is important (Levy and Reiche, 2017). Being proactive during this change often requires taking self-initiated action to alter the social environment or challenge the status quo (Grant and Rothbard, 2013). This may involve seeking new information, building networks or seeking feedback, rather than waiting for external guidance (Thompson, 2005). Proactiveness may also involve the development of initiatives to create a more favourable platform for increased social interaction within these networks. Changes in formal structure affect the relationships that actors develop within their networks but there is very little understanding of how the social skill of subsidiary actors helps create and leverage important social interactions with corporate HQ during significant structural transitions (Kostova and Roth, 2003; Lynch and Mors, 2018). The 'dark side' of developing regular social interactions, which may lead to negative experiences or be perceived as a 'waste of time' by 
executives, creating distrust or suspicion, has also been largely ignored in the extant literature (Bouquet, Barsoux and Levy, 2015; Gargiulo and Benassi, 2000; Labianca and Brass, 2006; Liebeskind et al. 1996).

Another major limitation of studies on the micro-political perspective of the MNE is that they overlook the importance of political skill in establishing influence (Geppert and Dorrenbacher, 2014). Despite social skill often determining who individual actors are connected to (Inkpen and Tsang, 2005; Kostova and Roth, 2003), political skill determines the particular tactics that individuals use to influence or leverage such connections (Blass and Ferris, 2007; Cullen et al. 2015; Harvey and Novicevic, 2004). In the subsidiary context, political skill may involve the ability to gain 'specific support' from corporate HQ when a proposal is being presented (Molloy and Delany, 1998). Political skill may involve effectively reinforcing particular subsidiary characteristics or successes so that corporate decision makers are aware of the value and relevance of these characteristics (Dorrenbacher and Gammelgaard, 2016). Those who are politically adept may be effective at developing a reputation for being an expert in a certain area and constantly seek to reinforce this (Pfeffer, 1978). However, political skill involves assertiveness and conviction (Molloy and Delany, 1998), but actors may risk over-promoting, over-selling or misdirecting influence attempts, creating negative reputational effects (Conroy and Collings, 2016). Individuals who are highly skilled politically may risk being perceived as selfinterested or subversive if they are using ineffective influencing tactics (Ferris et al. 2007). How individuals use political skill to coercively influence decisions for their self-interest and the negative effects this may have on the rest of the organisation has largely been overlooked in the context of research on political skill (Zettler and Lang, 2015).

Based on the preceding argument, it is clear that, as the MNE structure shifts to a more networked architecture, we need to develop a greater appreciation of how subsidiary influence is 
developed through the social and political undertakings of key subsidiary actors. As such, the main aim of this study is to explore how subsidiary actors use their social and political skills to augment and enrich subsidiary influence in the context of mandate change.

\section{METHODOLOGY}

The current study is qualitative in nature as qualitative research is uniquely suited to exploring how social and political exchanges take place in micro-level interactions within the MNE (Dorrenbacher and Gammelgaard, 2016). We utilised a multiple case study research design as it generally provides more robust and compelling evidence than a single case, allowing for the development of a more complete theoretical representation (Yin, 2009). Exploratory case study research is particularly appropriate for exploring the early stage relationship between complex and dynamic issues (Eisenhardt, 1989; Gibbert, Ruigrok and Wicki, 2008). The extant literature has called for more qualitative case studies in the IB field in general (Birkinshaw et al. 2011; Cuervo-Cazurra et al. 2016; Welch et al. 2011) emphasising the value of case studies as an appropriate tool for investigating social and political dynamics in MNEs (Dorrenbacher and Gammelgaard, 2016; Geppert and Dorrenbacher, 2014; Levy and Reiche, 2017). As such, case

studies are uniquely suited to opening the black box of 'how', 'who' and 'why' questions (Doz, 2011) in the context of corporate HQ-subsidiary relationships (Collings and Dick, 2011).

The selection of the cases was motivated by the need to find rich evidence of social and political dynamics during mandate change. Therefore, 6 subsidiaries of U.S MNEs operating in Ireland were chosen and pseudonyms are used to provide anonymity. Cases were identified in accordance with theoretical sampling and selected on their suitability for extending relationships and logic among constructs (Yin, 2009). This sampling criteria focused on U.S. MNE subsidiaries operating in the medical devices industry, in a specific geographical location, the Mid-West region of Ireland, which have recently extended or renewed their mandates through 
corporate investment. Our logic is that the outcome of mandate development provides a context to explore subsidiary influence, and in particular the micro-level interactions between power actors (Dorrenbacher and Gammelgaard, 2016). In some instances, examples of mandate loss were also identified. All 6 subsidiaries are major employers in their local region and all have advanced or important mandates with significant experience in gaining and losing investment from corporate HQ. Therefore, we controlled for the types of mandates subsidiaries had in order to set the foundation for how social and political skills of subsidiary actors manifested in their interactions with corporate HQ. Case firms were chosen based on similar characteristics required to be included in our study. Yin (2009) terms this form of case design literal replication, in that multiple cases produce similar and more robust results. The cases were comparable in the sense that, rather than observing contrasting patterns across cases, we focused on clarification, replication and extension of emergent findings across the cases (Eisenhardt and Graebner, 2007). This form of replication logic enhances the validity and sharpens the focus of relationships between constructs and the underlying reasons of why these relationships exist (Eisenhardt, 1989).

\section{Data collection}

Semi-structured in-depth interviews were the main source of data collection. A total of 50 interviews were carried out and of these 47 were conducted with top management across the 6 subsidiaries. In identifying respondents for interview, we utilised purposive sampling techniques. We were conscious of developing breadth rather than depth and the majority of respondents held regional or global roles within their respective subsidiaries. We targeted subsidiary actors as ‘corporate elites' or 'knowledgeable agents' (Gioia, Corley and Hamilton, 2013), knowing that 'the higher the status of the company informant interviewed the more reliable and powerful the data' (Welch et al. 2002: 613). All of these interviewees were host country nationals with the exception of one expatriate. Three interviews were carried out with representatives from 
institutions in the local environment to provide further context. Interviews lasted between 90 to 120 minutes and were all conducted at the respondents' places of work. Interviews were digitally recorded, transcribed verbatim, and stored in case files along with extensive interview case notes. Table 1 outlines the interviewee profiles within each of the 6 subsidiaries.

\section{INSERT TABLE 1 HERE}

Documentary evidence (Table 2) was collected on each case firm, through company websites, annual reports and press releases to provide extensive company profiles (Gibbert et al. 2008). These profiles aimed at capturing corporate HQ's perspectives, which were only partially represented in our primary data. We sought to partially capture this perspective by asking interviewees for their perception of corporate HQ's perspective. We follow other studies in assuming the high validity of these perceptions as many of the respondents had previously held roles at, or embarked on assignments to, corporate HQ within their respective MNEs (Dorrenbacher and Gammelgaard, 2016).

\section{INSERT TABLE 2 HERE}

\section{Data analysis}

Data analysis was constructed along the lines of abductive reasoning, in that data were analysed in tandem with the data collection through a nonlinear iterative research design (Dubois and Gadde, 2014). Matching and redirection between existing theory on micro-politics and subsidiary influence, and the new data being collected, allowed for the emergence of original theoretical constructs within the analysis process (Van Maanen, Sorensen and Mitchell, 2007). In this way, new conceptual insights, related to existing theories, emerged from the data, allowing for the creation of more refined theoretical insights as the analysis progressed (Dubois and Gadde, 
2014). The interview protocol was 'guided' by theoretical frames of reference from the literature on subsidiary influence and micro-politics, in order to provide 'structural signals' (Dabos and Rousseau, 2004) for 'probing' interviewee' thoughts. These signals formed the key questions asked to interviewees, aimed at qualifying the context of the subsidiary actor's social and political approaches to influencing corporate HQ.

Data from each case were collected individually and sequentially. We conducted within-case analysis and subsequently cross-case analysis (Yin, 2009). We developed themes and codes that illustrated the derivation of theoretical constructs from the data in order to enhance the reliability of our findings (Cuervo-Cazurra et al. 2016; Gioia et al. 2013). Initially, in the 'open coding' stage we identified first order codes, derived from and aligned with interviewee's terminology on subsidiary influence. Second order codes were subsequently created by categorising first order codes and grounding them in theoretical language on subsidiary influence and micro-politics in particular. Finally, we developed overall theoretical aggregate themes, based on the first and second order codes, derived from the raw data, existing literature and emerging themes. An example of this coding process is represented in the following quote, 'everything you do you are really trying to market the site' (Senior Manufacturing Director MEDCO), which we coded as 'marketing success' (first order) and 'showcasing' (second order) as a form of 'political manoeuvring' (aggregate theme).

\section{FINDINGS}

The following section describes the specific ways that subsidiary actors across the 6 case firms used their social and political skills to gain access to and subsequently influence corporate counterparts. 


\section{Socially and politically inactive}

A number of respondents were adamant that they did not value being socially or politically active, believing the 'destiny' of their mandates was solely determined by corporate HQ. For example, despite SINCO being one of the top three most strategically important subsidiaries, within an internally competitive MNE, a number of subsidiary interviewees were not as socially or politically active as the subsidiary's mandate permitted. Focusing on the execution of their existing mandate and taking orders from corporate HQ was perceived by some respondents as the most effective way to 'play the corporate game'. Respondents added that being too socially and politically active was potentially a risky approach, as they feared a negative reaction from others within the MNE if viewed as self-serving. SINCO was an example of a case that had recently suffered from mandate loss. PHARMCO was a further example of a case that was not as successful in developing its mandate as other cases in our study. PHARMCO's Financial Controller suggests, 'we would not necessarily go touting for business... we feel we would be stepping out of line and we would not like anyone else to do it'. As such, fear of negative consequences and the need to be seen as 'good corporate citizens' were major drivers for not being socially or politically active and led to outcomes of either mandate loss or a lack of significant mandate development compared to other firms. Despite this, the majority of respondents were socially and politically engaged with corporate HQ, resulting in both progressive and adverse outcomes to their mandates.

\section{Social navigating}

Respondents articulated the importance of being able to continuously create, maintain and develop spaces of social engagement with key decision makers at corporate HQ. Given the complex reporting lines and continuously changing social environment regularly evident within MNEs, it was important for subsidiary actors to draw on social skill to create greater levels of social engagement with key corporate decision makers. As such, social navigating involved key 
subsidiary actors leveraging their social skill to develop a platform for implementing political influence tactics. The importance of social navigating was driven mainly by the historical lack of social engagement with key decision makers in most subsidiaries. We identify a lack of necessary social skills as having a key impact in this regard. Subsequent changes in leadership teams have allowed respondents to develop more deliberate means of social engagement. The comment below outlines how this played out at HEALTHCO:

Back in the mid-nineties the leadership of the plant was recognised as very territorial and parochial and did not engage very well with corporate...there would have been an attitude of 'we will sit and listen to the yanks for two days and then we will go back to what we were doing'. There is now much more engagement. [The subsidiary] are actively seeking support from the corporate, encouraging people to come over, in fact requesting it (VP HEALTHCO).

We define social space as a context for social interaction between key actors, which can manifest both formally and informally. As such, social navigating was undertaken through both formal and informal avenues. Formally, many subsidiary actors leveraged their global roles within the subsidiary, or previous expatriate assignments, to purposefully create and develop greater spaces of social engagement. Such global roles allowed for direct reporting lines and more open communication channels that are important for building relationships. As CHEMCO's VP of Regulatory Affairs states, 'we are making sure we have the right people at the right table, if you have a particular job it is easy to get the right people in the right space'. A willingness to undertake international assignments was also cited as a formal way to create more social engagement with corporate executives. Many of the respondents outlined how they have strategically used previous assignments as 'stepping stones' to navigate the social hierarchy within the MNE;

My latest global assignment would not have been possible only for my last position. That position would not have been created if I had not taken the step a few years ago for the 
previous position and now we have that and we also have another management position where we have more ownership and responsibility (R\&D Manager PHARMCO).

Social navigating also transpired through informal channels beyond the formal mandate. Respondents invested significant resources and time into informally engaging with corporate HQ through informal interactions that are 'not written in the charter, but that's just the reality of it' (Senior R\&D Manger VASCA). Respondents were deliberate in creating informal 'corridor conversations' to 'understand who the movers and shakers are' (R\&D Manager MEDCO) as 'decision making depends a lot on building your networks and communication channels if you do not work with these guys and meet them stimulate relationships with them... a lot of relationship building is on an informal basis' (NPD Manager CHEMCO). In other words, 'there is a lot that goes on behind the scenes' (Senior R\&D Manager MEDCO), 'so we are kind of sowing seeds around the place' (Process Development Manager SINCO). An important part of how these formal and informal avenues were created and maintained involved social proactiveness and social flexibility within the changing social hierarchy of the MNE.

\section{Proactiveness}

In most of our cases, respondents indicated the importance of being socially proactive in navigating informal channels of engagement. In this sense, social proactiveness is defined as the development of initiatives to create a more favourable platform for increased social engagement with key decision makers. Respondents cited how they regularly attempted to create more opportunities to visit corporate HQ as well as invite executives to the subsidiary. As noted by the Engineering Manager at PHARMCO, 'you have got to get over there, it is invaluable, plus having them here, it is about taking the time to get to know people'. Managers would deliberately send subsidiary 'champions' on these visits that had the capacity to build relationships and involve people in what we were doing'. A major motivation for this approach was that respondents knew they were not as close geographically to corporate HQ as other subsidiaries and perceived they 
needed to be more 'well connected' socially as they feared their mandates were vulnerable to depletion if they were not continuously searching for opportunities to engage with decision makers. The HR Manager at MEDCO noted that, 'you have to be seen over there. You will lose touch, if I wasn't over there I would just be a name that's in a remote location doing some good work but now we have a name and a relationship and its very different'. Interestingly, respondents in some cases noted that being socially proactive often leads to opportunities for other subsidiary actors being promoted to more global roles across the MNE or at corporate HQ. The quote below reflects these insights;

\begin{abstract}
We are looking to improve the relationship. As the group are getting bigger, everybody kind of calls me, so one of the things that is very important is that promoting the new people, so getting the guys to travel and getting them to meet their peers and the senior people over there [corporate HQ] so that they will get a flavour (R\&D Manager CHEMCO).
\end{abstract}

\title{
Flexibility
}

Being flexible in adapting to continuously changing structures so that further levels of social engagement could be maintained and developed was an important part of social navigating. Flexibility in this regard involved having the ability to adapt to a changing social environment by maintaining existing social relationships or creating new social relationships. Respondents outlined that their respective MNEs have become more complicated due to varied reporting lines or decision structures and continuous changes to key personnel. As a result, social relationships they had built up with key decision makers may be disrupted or risk becoming obsolete if key individuals left their roles or were replaced with others who may have their own political motivations. As an example, respondents at CHEMCO are heavily dependent on the close social relationship they have built up over time with their CEO and the subsidiary may be vulnerable to any change in this regard. Other respondents cited how changes in executive 
personnel have negatively affected their ability to tap into social relationships they had developed over time. The following comments are indicative of these insights:

Long term [the CEO] will not be part of the executive management so who replaces him and how the organization is going to be managed is going to be one of the key challenges, so positioning ourselves so that we operate irrespective of who is at the helm and have the capability to adapt quickly (VP of Regulatory Affairs CHEMCO).

When I took over my first job, the VP I was exposed to...he and I had a great relationship... he was supportive of building up a core in [the subsidiary]. When he left the next VP was German and he had no problem with wearing black, red and yellow ${ }^{1}$ and everyone knew that (R\&D Director for VASCA).

Flexibility is also important in maintaining social engagement with key decision makers particularly when acquisitions occur. Acquired companies were frequently rationalised across the MNE and often resulted in mandate extensions for subsidiaries. Subsidiary actors realised that being 'well connected' to key decision makers would provide them with a timely platform to potentially benefit from this restructuring. As such, respondents were extremely conscious that the social relationships they built up were key for taking advantage of acquisition opportunities. As the Engineering Manager at PHARMCO notes;

When there is an acquisition then you are the number one name on the senior management team's list or when they are going to develop a new product and make a decision on where to put it, you want to be the first person there for it.

\section{Social stability}

Some respondents tended to overuse their social skill in certain instances and eventually it led to

a form of social imbalance in the subsidiary management team. For example, the VP at

HEALTHCO stated that too much 'plámásing'? happened in the past in that the subsidiary had

\footnotetext{
${ }^{1}$ This is a euphemism for saying that the German VP was nationalistic in his approach and was biased toward the German subsidiaries in the MNE.

${ }^{2}$ This is an Irish colloquial term for ingratiating or flattery behaviour.
} 
been criticised by corporate HQ and other subsidiaries for 'overdoing it' when socialising with corporate HQ:

When people came to [Ireland] one of the problems we had was they [corporate HQ] would always complain about the journey from Dublin...so I started to get the plant guys to lay on taxis for the Americans who would be tired when they arrive in so they do not want to drive on the wrong side of the road. Taxis at that time were about 300 euros so I said let's organize taxis for them even if they are only technicians, who cares.

Respondents stated that a drawback of being more socially engaged within the MNE was that it led to changes to personnel in the subsidiary management team. A number of respondents talked about maintaining a 'social stability' within the subsidiary management team; 'it is very much a global team but there is a concentration of that team now based in [the subsidiary]. It is important from [the subsidiary] standpoint to have everybody operating out of here' (VP MEDCO). As the subsidiaries' mandates became more global and interconnected, having 'people with no skin in the game' operating of out of the subsidiary was considered a major threat. In this sense respondents favoured local subsidiary actors holding global roles in the subsidiary, but they were protective against 'outsiders' being expatriated to the subsidiary. Some respondents were extremely assertive in combating against any potential changes to personnel and protecting key roles within the subsidiary. As the Plant Manager at HEALTHCO stated, 'when you have non [Irish] nationals moving into plant positions they have a different agenda, of personal gain and that could be the beginning of the end'.

An important theme that emerged was that although social skill was used to establish greater levels of social engagement with corporate executives, respondents were cognisant that this would not necessarily lead to influence. As the Director of R\&D for MEDCO noted, 'those contacts are at the right table, and half a connection back to here. It is beneficial, but the site has to be able to show the benefit to these contacts and they will then help drive that'. In this regard, 
it was evident that subsidiary actors concomitantly needed to use their political skill to exert influence over corporate executives.

\section{Political manoeuvring}

A number of respondents actively engaged in political manoeuvring, which involved leveraging political skill to implement specific influence tactics such as targeting, showcasing and framing when interacting when corporate decision makers. SINCO's Process Development Manager outlines the nature of this political manoeuvring;

It is pure politics, it is brutal. People nodding and winking all the time. We are kind of openly admitting to playing games in the multinational arena. We have all these corporate rules, which everybody just ignores.

\section{Targeting}

Respondents used 'targeting' tactics to influence particular corporate executives with certain projects, through key functions in specific ways. Therefore, we define targeting as committing time, resources and effort into developing specific initiatives, products, projects or functions. Interestingly, respondents targeted products that they believe the corporate HQ has not effectively developed or failed to develop in the past, as the VP of Process Development at SINCO states, 'sometimes we will start to develop a process that has been tried in [corporate HQ] and we feel that through either our own knowledge or education that it might be better to use a different technology'. Political skill was also targeted through certain subsidiary functions, mainly R\&D operations, as these are valuable and constantly shifting mandates within most of the subsidiaries;

The political domain in managing $\mathrm{R} \& \mathrm{D}$ is huge. You cannot expect to manage $\mathrm{R} \& \mathrm{D}$ in an offshore context without being politically acute. Especially when you are fighting the culture of 'it should only be done in the U.S.'. In order to overcome that the political skills 
of the R\&D organisation need to be quite significant. People like myself and [two other subsidiary managers] need to be very tuned into that (R\&D Director VASCA).

Targeting also involved identifying and leveraging the preferences of key contacts in corporate HQ that were already established through social navigating. Knowing the specific preferences of key decision makers or 'gatekeepers' was a critical targeting tactic, for example, one respondent noted that their new CEO was very much focused on 'cost saving', whereas another respondent noted their CEO wanted to develop a new 'talent management' system. Both subsequently targeted their efforts to developing initiatives around those particular preferences. As such, although social navigating was about developing greater levels of engagement and interaction with key decision makers, targeting in this sense was knowing exactly what the preferences or 'hot buttons' of these 'influencers' were and subsequently targeting resources toward the creation and development of specific initiatives that addressed these preferences. Respondents were skilled at adapting their targeting tactics to the preferences of these gatekeepers stating 'you have people that are more political than others' (Plant Manager PHARMCO). In addition to targeting, respondents channelled their political skill through showcasing and framing tactics.

\section{Showcasing success}

Political skill was channelled through influence tactics of showcasing success where respondents made corporate executives aware of the specific activities or initiatives that were successfully developed in the subsidiary. For example, 'everything you do you are really trying to market the site and make sure you are creating the right impression' (Senior Manufacturing Director MEDCO). Respondents emphasised showcasing their success through annual and quarterly reviews or ad-hoc visits, and subsidiary actors would 'not be shy' in showcasing prototypes or making corporate HQ aware of new initiatives. Respondents mentioned that it was important that the subsidiary was 'prepared for it [corporate HQ visit], make sure if there was a new initiative that you had that strategically placed' (Financial Controller PHARMCO). Respondents 
pointed to particular presentations they did with corporate and the importance of the detail and research beforehand:

If there is an exciting topic we would do a couple of slides on, just to give them a bit more comfort. Getting validation or positive feedback from clinicians is also good before we go into these meetings. Being able to communicate that is very important and they are aware of it. And we can get focus from that (Senior R\&D Manager VASCA).

Furthermore, respondents politically targeted difficult or complex projects, that other subsidiaries or even corporate executives would not undertake, but subsequently showcased the success from executing these projects as the basis for gaining further investment. This was a targeted showcasing strategy common across subsidiary actors who were politically astute;

[Corporate HQ] made it out to be an absolutely monstrous project, which it was not, corporate bought the whole thing...it came in on time and on schedule and corporate were drooling at this great execution and in reality it was easier...for the plant here it was a huge feather in our cap. We subsequently won a massive project that is going on now in $\mathrm{R} \& \mathrm{D}$ and it is the biggest project in the corporation (Process Development Manager SINCO).

\section{Framing problems}

An important part of subsidiary actors' political skill was how they framed problems at the subsidiary to corporate executives. A number of the subsidiaries in one of our cases had previously faced a product recall that 'dented corporate confidence' (MD SINCO), and eventually lead to the partial loss of a mandate at the VASCA subsidiary. Hence, subsidiary actors became even more politically active when problems or setbacks arose as they were acutely aware that 'you are only as good as your last mistake' (VP Process Development SINCO). As such, respondents used their political skill to frame problems in different ways. Some politically naive respondents outlined how they managed problems 'under the radar' but when they escalated and corporate HQ were eventually made aware, it resulted in tensions. Other politically savvy respondents stated that it was important not to remain silent and 'sit on problems' or 
issues and instead disclose them early, but more importantly to frame them with a plan on how they may be solved:

It is really about not just saying we have a problem, but about saying we have a problem and this is what we are doing about it. You advise them [corporate HQ] about an upcoming issue so you also have your own plan so you want to give them confidence that everything that can be done about it is being done, you do it in a way that promotes the confidence that it is a safe pair of hands (VP Director of Manufacturing MEDCO).

Framing in a relative sense was particularly useful when there were problems at other competing subsidiaries that were not dealt with effectively as it allowed subsidiary actors to use this as an opportunity. As the Plant Manager at HEALTHCO states, 'where we have done better than say some of the other plants, they have tended to have surprises, nasty surprises, financial surprises or otherwise... we have been better able to manage when things go wrong'.

\section{Strategic repositioning of the subsidiary mandate}

An important outcome of how subsidiary actors leveraged their social and political skill was the deliberate strategy to 'reposition' the subsidiary's mandate over time within the MNE. Strategic repositioning involved the continuous social navigating and political manoeuvring of subsidiary actors in order to incrementally develop the mandate up 'the strategic staircase' (R\&D Director MEDCO). In some ways, repositioning the mandate was not a straightforward development process driven by corporate investment or a deliberate subsidiary plan, but more an unstructured intermittent activity that was dependent on how skilled subsidiary actors were in 'freeing up space' by, 'moving higher value products in' and 'lower value products out' (Plant Manager PHARMCO). This often took place in the context of skilled subsidiary actors anticipating and taking advantage of significant structural changes across the MNE to eventually reposition the subsidiary's mandate at the higher end of the value chain. The NPD Manager at MEDCO articulates how this strategic repositioning worked, it is difficult to know what is coming down 
the road, it could be a major investment or a major cut, so you have to position your base broad enough...you want to be in a position when that opportunity arises'.

Most subsidiaries had advanced mandates and as a result reached full capacity in terms of physical space, so bringing in more R\&D from corporate HQ meant firstly having to illustrate that they had the physical space to perform the R\&D activities. Interestingly, in this context, subsidiary actors in global roles leveraged their political skill to strategically reposition the subsidiary's mandate within the MNE, often at the expense of the rest of the MNE. For example, a number of respondents outlined how they had the opportunity to influence significant investment decisions by altering the overall structure of the MNE, securing long term investment into the subsidiary and ultimately repositioning the mandate. In contrast, respondents in other subsidiaries (VASCA) failed to leverage their political skill in this way, and this political naivety contributed to the loss of their subsidiary's mandate at the time. The two quotes below are indicative of these contrasting examples:

I have moved four or five hundred jobs out of here to Mexico...some people thought I was crazy moving stuff to Mexico they thought it might jeopardise the business. The Irish subsidiary now realise that we cannot compete with Mexico anymore from a cost structure point of view but that we have to use them so that our overall cost structure looks better. Outsourcing the labour intensive activities has helped secure what the Irish subsidiary has left (VP MEDCO).

The decision to close the subsidiary was very much one of timing and politics. In my discussion with corporate they were asking me why I would not close the R\&D facility in the U.S. and move it to [Ireland]. So, I had all the Americans asking me to close down the R\&D facility in their own back yard and ship it to [Ireland]. In reality what I wanted to do at the time was close down Germany and Switzerland and create two poles of R\&D between [Ireland] and [corporate HQ] (R\&D Director VASCA).

Based on the above findings we define social skill as the ability to continuously create, maintain and develop spaces of social engagement with key decision makers. This involves being proactive and flexible while maintaining social stability in the subsidiary management team. Political skill is defined as the ability to leverage social spaces by developing specific influence tactics. How these 
skills are leveraged may impact the strategic repositioning of the subsidiary's mandate within the MNE. Figure 1 includes our data structure along with illustrative quotes for each of the above arguments.

\section{INSERT FIGURE 1 HERE}

\section{DISCUSSION}

The significant shift from a hierarchical to a networked MNE has challenged how the subsidiary manages its changing relationship with corporate HQ and has created a 'high stakes' political contestation in the struggle to develop and maintain influence (Egelhoff and Wolf, 2017; Levy and Reiche, 2017). Despite calls to explore how the subsidiary can cultivate greater influence in this context, extant research has largely failed to address the ongoing micro-level interactions that take place on a daily basis between key actors at the corporate HQ-subsidiary interface (Geppert and Dorrenbacher, 2014; O’Brien et al. 2018; Pla-Barber et al. 2017). By exploring how subsidiary actors use their social and political skills to augment and enrich subsidiary influence in the context of mandate change, our study makes two important theoretical contributions. First, drawing insights from a micro-political perspective of the MNE (Clegg et al. 2018; Dorrenbacher and Gammelgaard, 2016; Geppert et al. 2016; Kristensen and Zeitlin, 2005; Morgan and Kristensen, 2006), we provide a more nuanced micro-level understanding of subsidiary influence, by illuminating the importance of the social and political dimensions of subsidiary influence (Kostova and Roth, 2003; Levy and Reiche, 2017). We argue that subsidiary influence needs to be understood independently, at least in part, from the formal resources the subsidiary possesses and structures it operates in, and more so through the social and political undertakings of key actors in the context of mandate change. In doing so, we answer calls to explore further 'how power is socially enacted and how political manoeuvring is grounded in micro-level interactions' at the corporate HQ-subsidiary interface (Geppert and Dorrenbacher, 2014: 231). Second, and 
more specifically, we illustrate that a subsidiary can augment and enrich its influence in the context of mandate change by channelling the social and political skills of key subsidiary actors in particular ways. Our findings illustrate how social skill allows subsidiary actors to continuously create, maintain and develop spaces of social engagement with key decision makers, whereas political skill leverages social spaces to develop specific influence tactics in the form of targeting, showcasing and framing. In doing so, we answer calls for a refined conceptualisation of the nuanced differences between how social and political skills are used (Baron and Markman, 2000; Blass and Ferris, 2007; Cullen et al. 2015; Ferris et al. 2007; Harvey and Novicevic, 2004) and illuminate the concomitant value of these skills in the context of subsidiary influence. A major contribution of our study comes in the form of a typology of subsidiary actor influence roles, outlined in the next section.

\section{Typology of subsidiary actor influence roles}

Based on our findings, we have identified four particular types of subsidiary actor influence roles and we have categorised these as; recluse, political animal, socialite and strategic influencer. We define these roles by the degree of social navigating and political manoeuvring that subsidiary actors undertake. Social navigating involves the way in which subsidiary actors leverage their social skill to develop a platform for implementing political influence tactics. Political manoeuvring involves the way in which subsidiary actors leverage their political skill to implement particular influence tactics when engaging with corporate decision makers. Figure 2 presents a typology of these roles.

INSERT FIGURE 2 HERE

Our study identifies Recluse subsidiary actors, who are involved in low levels of social navigating and political manoeuvring as they are neither socially nor politically active and nor do they value 
engaging with or influencing corporate executives. Our findings show that even though the subsidiary's mandate may allow for autonomy and freedom to manoeuvre, recluse subsidiary actors are risk averse for various reasons. This may prove less prosperous or even destructive for the subsidiary's mandate. As such, although recluse actors may on occasion have the necessary social and political skills, they do not proactively draw on these skills to pursue the subsidiary agenda. They do not partake in political manoeuvring as they are fearful of being viewed as selfserving by corporate HQ or others. Equally, they are not involved in social navigating as they are often deterred by complex reporting lines and changing structures within the MNE. Further exploring the reasons why subsidiary actors that have the skills to develop the subsidiary's mandate, but fail to do so, is an interesting area that would address the lacuna of empirical work on the devolution of subsidiary mandates (Dorrenbacher and Gammelgaard, 2010; Galunic and Eisenhardt, 1996).

Political animals are those subsidiary actors that are highly involved in political manoeuvring and channel their political skill through specific influence tactics of targeting, showcasing and framing when engaging with key corporate decision makers. In borrowing insights from micro-politics (Dorrenbacher and Gammelgaard, 2016; Geppert and Dorrenbacher, 2014), our findings illustrate that political animals target their political efforts through key functions, initiatives or individual preferences and commit resources, time and effort into influencing corporate gatekeepers. We build on studies that show that subsidiary power resides within specific functions (Mudambi et al. 2014), but illuminate how specific influence tactics such as targeting, showcasing and framing may be channelled through the $R \& D$ mandate in particular due to the constant changes and desire for corporate executives to maintain control of their advanced operations. 
Political animals use their political skill to target difficult projects at corporate HQ and participate regularly in showcasing specific successes in executing these projects. We build on earlier studies that argue keeping corporate HQ informed of the subsidiary's activities may be an important way to overcome corporate HQ bounded rationality (Bouquet and Birkinshaw, 2008b; Ciabuschi et al. 2011; Conroy and Collings, 2016). Specifically, we expand on these insights by showing how targeted showcasing is an effective micro-political influence tactic. Regularly identifying and 'framing', rather than hiding, subsidiary problems in particular ways to corporate $\mathrm{HQ}$, and crucially developing plans to solve these problems is an important part of political manoeuvring. Being open and transparent when problems arise but subsequently framing them to corporate executives in a way that the problems may be solved with a clear plan is a subtle but influential political tactic. These insights contribute to the emerging political perspective of the MNE (Clegg et al. 2018; Geppert and Dorrenbacher, 2014; Geppert et al. 2016) and add a microlevel dimension to subsidiary influence studies by illuminating how influence is effectively carried out through the political targeting strategies of key subsidiary actors rather than haphazard broad-based influence approaches. More studies need to consider the specific nuances of political manoeuvring for understanding subsidiary influence in the context of a changing corporate HQ-subsidiary relationship (Conroy et al. 2017; Levy and Reiche, 2017).

Political animals may however use their political skill in ways that negatively impact the subsidiary's mandate. We find that as subsidiary actors take on global roles, their decisions have the ability to shape and 'dictate' the overall structure of the MNE. Politically astute actors are more likely to use their political skill in ways that benefit both the subsidiary and the wider MNE. However, politically subversive actors often fail to identify the dual advantages of these opportunities. This political subversion involves hiding problems or not disclosing issues until too late due overconfidence that a problem can be solved in isolation, or a belief that the corporate immune system may refuse the development of certain initiatives. As such, we address 
calls for further work on how self-interest and opportunism may impact the corporate HQsubsidiary relationship (Cavanagh et al. 2017; Mudambi and Navarra, 2004) by illuminating how key subsidiary actors may subversively abuse their political skill to benefit the subsidiary's agenda at the expense of the MNE. These insights also address shortcomings in considering the negative aspects of using political skill (Zettler and Lang, 2015) and how the politicising process affects the subsidiary's mandate (Birkinshaw and Ridderstrale, 1999). Further work is needed on how the disaggregation of corporate HQ responsibilities to key subsidiary actors may impact the overall structure of the MNE and create further complexity in maintaining subsidiary influence (Levy and Reiche, 2017; O’Brien et al. 2018; Pla-Barber et al. 2017).

Socialites are those subsidiary actors that are involved in high levels of social navigating, leveraging their social skill to create, maintain and develop spaces of social engagement that are a crucial platform for implementing political influence tactics. We illuminate how significant changes to the social hierarchy of the MNE may provide subsidiary actors with the opportunity to cultivate further social spaces for informally engaging key decisions makers. This insight answers calls to explore how subsidiary actors navigate the changing social hierarchy of the MNE (Levy and Reiche, 2017), by revealing how the social skill of subsidiary actors is an often overlooked requirement for 'gaining access' to decision makers at corporate HQ (Kostova and Roth, 2003; La Due Lake and Huckfeldt, 1998). Further, socialites are socially flexible, with an ability to adapt to changes across the MNE, such as increasingly complex reporting lines, more integrated decision structures or changes in personnel. These changes increase the importance of socialites becoming 'social chameleons' that are continuously adapting (Baron and Markman, 2000). Socialites are also highly socially proactive (Grant and Rothbard, 2013; Thompson, 2005) in actively promoting the capabilities of other subsidiary actors in order to develop informal relationships with corporate executives. As such, in order for subsidiary actors to be 'better positioned' than anyone to interact with and anticipate the critical needs of corporate decision 
makers (Kostova and Roth, 2003; Molloy and Delany, 1998), our findings emphasise the need to be socially proactive and flexible to continuously develop greater levels of social engagement.

Interestingly, our study reveals that socialites may inadvertently use their social skill in ways that exposes the subsidiary management team to changes in personnel, leading to key actors being exported from the subsidiary or strategic roles being filled by expatriates. Socialites in our case firms cited the socially homogenous nature and social stability of the subsidiary management team as a valuable condition for developing the subsidiary's mandate. Increasing informal social engagement with corporate HQ may lead to the threat of 'outsiders' being expatriated to the subsidiary, who may not be committed to the subsidiary's agenda. Although this may be a positive for the MNE, subsidiary actors viewed this as a threat to the development of the subsidiary's mandate over time, as it disrupts the social stability of the subsidiary management team. As such, a drawback for subsidiary actors being overly involved in social navigating with corporate HQ is that the subsidiary becomes an attractive location for other actors within the MNE to develop their individual careers. These insights contribute to studies seeking to explain the 'dark side' of socialising (Gargiulo and Benassi, 2000; Labianca and Brass, 2006; Liebeskind et al. 1996) by showing how using social skill to develop increased patterns of interaction may disrupt the social stability of the subsidiary management team. Equally, there is a danger of oversocialising to the point of resemblance with corporate HQ if too many expatriate managers become stationed in the subsidiary. In other words, we find that overly extensive socialisation or interaction with corporate HQ may dilute the subsidiary's uniqueness over time.

Strategic influencers are subsidiary actors that are involved in high levels of social navigating and political manoeuvring. These actors leverage the concomitant value of social skill and political skill to augment and enrich influence over corporate HQ. Strategic influencers use their social skill to develop greater levels of social engagement with corporate HQ while concomitantly using 
their political skill to develop influence tactics of targeting, showcasing and framing. The increased interaction that results from greater social engagement allows strategic influencers to channel their political skill for the development of both the subsidiary and the MNE. Strategic influencers are socially and politically astute so that they avoid disrupting the social stability of the subsidiary while also avoiding being viewed as self-serving. Strategic influencers are proactive and flexible, and use targeting, framing and showcasing approaches, which over time leads to a strategic repositioning of the subsidiary's mandate. Strategic repositioning in this regard is defined as a continuous process of social navigating and political manoeuvring undertaken by key subsidiary actors to gradually and subtly reposition the subsidiary's mandate in the corporate value chain.

Interestingly, we find that strategic repositioning was not a straightforward development process driven by corporate investment or a rational subsidiary plan. In contrast to most previous studies on mandate change (Birkinshaw and Hood, 1998), we identify strategic repositioning as an unstructured intermittent activity that was dependent on how skilled subsidiary actors were at 'freeing up space' for higher value-added products. As such, repositioning of a subsidiary mandate is similar to the idea of 'upgrading' (Burger et al. 2017), but 'upgrading' foregrounds the subsidiary's formal resources, whereas our findings point to the importance of continuous sociopolitical interactions with corporate decision makers in incrementally readjusting the fluid position of the subsidiary's mandate in the context of a changing MNE structure. This contributes to a more nuanced and fine-grained understanding of mandate change by explicating how subsidiary influence is not solely determined by the formal resources it possess but more so by the particular micro-level skills that strategic influencers draw on and deploy. In doing so, we argue that current studies have largely overlooked the fact that the subsidiary's mandate is characterised by significant levels of variability and ambiguity (see Alfoldi et al. 2017) given the changes in its relationship with corporate $\mathrm{HQ}$ and the resulting political contestations. 
Interestingly, we also illustrate how partial mandate loss for the subsidiary may not be zero sum game as it may lead to greater scope to attract investment in responsibilities that lead to a higher value-added mandate. In strategically repositioning a subsidiary's mandate higher up the value chain, a partial loss to lower value-added responsibilities may be a strategic necessity in the short term. As such, the parallel effects of social skill and political skill of key subsidiary actors are central to augment and enrich influence in the context of strategically repositioning the subsidiary's mandate.

We acknowledge several limitations of the current study and point to opportunities for future research. We are aware that a case study approach may limit the statistical generalisability of the study (Yin, 2009). However, in line with the tradition of qualitative research, our aim was to generalise to theory as opposed to seeking generalisability in a more positivistic sense (Eisenhardt and Graebner, 2007). This form of 'analytical generalisability' was achieved by providing a clear rationale for the case study selection with ample details of the cases and giving a reasoned appreciation for sampling choices (Gibbert et al. 2008). Our study explored the subsidiary relationship with corporate HQ but further work should focus on the importance of the subsidiary-to-subsidiary relationship and the impact this relationship has on subsidiary influence. Empirical research should further explore the importance of the subsidiary actor in terms of the changing roles and identities they develop as they acquire and develop more advanced mandates. Such research could explore subsidiary influence incorporating theoretical insights from upper echelons theory and resource dependence theory. Furthermore, it would be interesting to explore how subsidiary actors, operating in boundary spanning roles, act as high-level intermediaries in balancing global and local power tensions. Studies should explore further how both hierarchical and networked-based structures may co-exist and the explicit impact that regional and divisional HQs have on the corporate HQ-subsidiary relationship. Although our study focused on the social and political skills of subsidiary actors, future research could explore other important skills 
and characteristics of those individuals with more work needed from a micro-foundations perspective.

\section{CONCLUSION}

This study provides a nuanced and fine-grained micro-level perspective of subsidiary influence. Social skill is used to continuously create, maintain and develop spaces of social engagement with key decision makers, whereas political skill leverages these social spaces by developing specific influence tactics in the form of targeting, showcasing and framing. As such, social skill and political skill are complementary micro-level factors for subsidiary actors that lead to a strategic repositioning of the subsidiary's mandate. Ultimately, effectively navigating the social hierarchy of the MNE provides a platform for 'taking aim' and executing political manoeuvring tactics. 


\section{REFERENCES}

Alfoldi, E. A., McGaughey, S.L. and Clegg, J. L. (2017). Firm Bosses or Helpful Neighbours? The Ambiguity and Co-construction of MNE Regional Management Mandates. Journal of Management Studies, 54(8), 1170-1205.

Ambos, B., Asakawa, K. and Ambos, T.C. (2011). A dynamic perspective on subsidiary autonomy. Global Strategy Journal, 1(3-4), 301-316.

Ammeter, A.P., Douglas, C., Gardner, W.L., Hochwarter, W.A. and Ferris, G.R. (2002). Toward a political theory of leadership. The Leadership Quarterly, 13(6), 751-796.

Andersson U., Forsgren, M. and Holm, U. (2007). Balancing subsidiary influence in the federative MNC: a business network view. Journal of International Business Studies, 38(5), 802-818.

Asakawa, K., Park, Y., Song, J. and Kim, S.J. (2017). Internal embeddedness, geographic distance, and global knowledge sourcing by overseas subsidiaries. Journal of International Business Studies, 1-10. https://doi.org/10.1057/s41267-017-0112-x

Baron, R. A. and Markman, G. D. (2000). Beyond social capital: How social skills can enhance entrepreneurs' success. The Academy of Management Executive, 14(1), 106-116.

Becker-Ritterspach, F.A., Blazejewski, S., Dorrenbacher, C. and Geppert, M. eds. (2016). Micropolitics in the multinational corporation: Foundations, applications and new directions. Cambridge University Pres.

Birkinshaw, J. (1996). How multinational subsidiary mandates are gained and lost. Journal of International Business Studies, 27(3), 467-495.

Birkinshaw, J., Brannen, M.Y. and Tung, R.L. (2011). From a distance and generalizable to up close and grounded: Reclaiming a place for qualitative methods in international business research. Journal of International Business Studies, 42(5), 573-581.

Birkinshaw, J. and Hood, N. (1998). Multinational subsidiary evolution: Capability and charter change in foreign owned subsidiary companies. Academy of Management Review, 23(4), 773-795.

Birkinshaw, J. and Ridderstrale, J. (1999). Fighting the corporate immune system: a process study of subsidiary initiatives in multinational corporations. International Business Review, 8(2), 149-180.

Blass, F. R. and Ferris, G. R. (2007). Leader reputation: The role of mentoring, political skill, contextual learning, and adaptation. Human Resource Management, 46(1), 5-19,

Bouquet, C., Barsoux, J. L. and Levy, O. (2015). The perils of attention from headquarters. MIT Sloan Management Review, 56(2), 16.

Bouquet, C. and Birkinshaw, J. (2008a). Managing power in the multinational corporation: How low-power actors gain influence. Journal of Management, 34(3), 477.

Bouquet, C. and Birkinshaw, J. (2008b). Weight versus voice: How foreign subsidiaries gain attention from corporate headquarters. Academy of Management journal, 51(3), 577-601.

Burger, A., Jindra, B., Marek, P. and Rojec, M. (2017). Functional Upgrading and Value Capture of Multinational Subsidiaries. Journal of International Management. https://doi.org/10.1016/j.intman.2017.09.004

Cantwell, J. and Mudambi, R. (2005). MNE competence-creating subsidiary mandates. Strategic Management Journal, 26(12), 1109-1128.

Cavanagh, A., Freeman, S., Kalfadellis, P. and Cavusgil, S.T. (2017). How do subsidiaries assume autonomy? A refined application of agency theory within the subsidiary-headquarters context. Global Strategy Journal, 7(2), 172-192.

Ciabuschi, F., Forsgren, M. and Martin, O. (2011). Rationality vs. ignorance: The role of MNE headquarters in subsidiaries' innovation processes. Journal of International Business Studies, 42(7), 958-997.

Clegg, S., Geppert, M. and Hollinshead, G. (2018), Politicization and political contests in contemporary multinational corporations. Human

Relations. https://doi.org/10.1177/0018726718755880 
Collings, D.G. and Dick, P. (2011). The relationship between ceremonial adoption of popular management practices and the motivation for practice adoption and diffusion in an American MNC. The International Journal of Human Resource Management, 22(18), 3849-3866

Conroy, K. M. and Collings, D. G. (2016). The legitimacy of subsidiary issue selling: Balancing positive \& negative attention from corporate headquarters. Journal of World Business, 51(4), 612627.

Conroy, K. M., Collings, D.G. and Clancy, J. (2017). Regional Headquarter's Dual Agency Role: Micro-political Strategies of Alignment and Self-interest. British Journal of Management, 28(3), 390406.

Cuervo-Cazurra, A., Andersson, U., Brannen, M.Y., Nielsen, B.B. and Reuber, A.R. (2016). From the editors: Can I trust your findings? Ruling out alternative explanations in international business research. Journal of International Business Studies, 47(8), 881-897.

Cullen, K. L., Gerbasi, A. and Chrobot-Mason, D. (2015). Thriving in central network positions: The role of political skill. Journal of Management, 44(2), 682-706.

Dabos, G. E. and Rousseau, D. M. (2004). Mutuality and reciprocity in the psychological contracts of employees and employers. Journal of Applied Psychology, 89(1), 52-72.

Delany, E. (2000). Strategic development of the multinational subsidiary through subsidiary initiative-taking. Long Range Planning, 33(2), 220-244.

Dorrenbacher, C. and Gammelgaard, J. (2006). Subsidiary role development: The effect of micropolitical headquarters-subsidiary negotiations on the product, market and value-added scope of foreign-owned subsidiaries. Journal of International Management, 12(3), 266-283.

Dorrenbacher, C. \& Gammelgaard, J. (2010). Multinational corporations, inter-organizational networks and subsidiary charter removals. Journal of World Business, 45(3), 206-216.

Dorrenbacher, C. and Gammelgaard, J. (2011). Subsidiary power in multinational corporations: the subtle role of micro-political bargaining power. Critical Perspectives on International Business, 7(1), $30-47$.

Dorrenbacher, C. and Gammelgaard, J. (2016). Subsidiary Initiative Taking in Multinational Corporations: The Relationship between Power and Issue Selling. Organization Studies, 37(9), 1249-1270.

Dorrenbacher, C. and Geppert, M. (2009). Micro-political strategies and strategizing in multinational corporations: the case of subsidiary mandate change. In Handbook of Research on Strategy and Foresight, Costanzo, L. A. and Bradley McKay, R. (eds). Edward Elgar: Cheltenham; 200-218.

Doz, Y. (2011). Qualitative research for international business. Journal of International Business Studies, 42(5), 582-590.

Dubois, A. and Gadde, L. E. (2014). Systematic combining - A decade later. Journal of Business Research, 67(6), 1277-1284.

Egelhoff, W. G. and Wolf, J. (2017). The role of headquarters in the contemporary MNC: A contingency model. In Multinational Corporations and Organization Theory: Post Millennium Perspectives, Dorrenbacher, C. and Geppert, M. (eds.) Emerald Publishing Limited; 71-98.

Eisenhardt, K. M. (1989). Building theories from case study research. Academy of Management Review, 14(4), 532-550.

Eisenhardt, K. M. and Graebner, M. E. (2007). Theory building from cases: Opportunities and challenges. Academy of Management Journal, 50(1), 25-32.

Ferris, G. R., Treadway, D. C., Perrewe, P. L., Brouer, R. L., Douglas, C. and Lux, S. (2007). Political skill in organizations. Journal of Management, 33(3), 290-320.

Forsgren, M., Holm, U. and Johanson, J. (2005). Managing the embedded multinational: A business network view. Cheltenham: Edward Elgar.

Foss, K., Foss, N. J. and Nell, P. C. (2012). MNC organizational form and subsidiary motivation problems: Controlling intervention hazards in the network MNC. Journal of International Management, 18(3), 247-259. 
Galunic, D. C. and Eisenhardt, K. M. (1996). The evolution of intracorporate domains: Divisional charter losses in high-technology, multidivisional corporations. Organization Science, 7(3), 255-282.

Garcia-Pont, C., Canales, J. I. and Noboa, F. (2009). Subsidiary strategy: The embeddedness component. Journal of Management Studies, 46(2): 182-214.

Gargiulo, M. and Benassi, M. (2000). Trapped in your own net? Network cohesion, structural holes, and the adaptation of social capital. Organization Science, 11(2), 183-196.

Geppert, M., Becker-Ritterspach, F. and Mudambi, R. (2016). Politics and power in multinational companies: Integrating the international business and organization studies perspectives. Organization Studies, 37(9), 1209-1225.

Geppert, M. and Dorrenbacher, C. (2014). Politics and power within multinational corporations: Mainstream studies, emerging critical approaches and suggestions for future research. International Journal of Management Reviews, 16(2): 226-244.

Gibbert, M., Ruigrok, W. and Wicki, B. (2008). What passes as a rigorous case study?. Strategic Management Journal, $29(13), 1465-1474$.

Gioia, D. A., Corley, K. G. and Hamilton, A. L. (2013). Seeking qualitative rigor in inductive research: Notes on the Gioia methodology. Organizational Research Methods, 16(1), 15-31.

Granovetter, M. (1985). Economic action and social structure: The problem of embeddedness. American Journal of Sociology, 91(3), 481-510.

Grant, A. M. and Rothbard, N. P. (2013). When in doubt, seize the day? Security values, prosocial values, and proactivity under ambiguity. Journal of Applied Psychology, 98(5), 810-819.

Harvey, M. and Novicevic, M. M. (2004). The development of political skill and political capital by global leaders through global assignments. The International Journal of Human Resource Management, 15(7), 1173-1188.

Inkpen, A. C. and Tsang, E. W. (2005). Social capital, networks, and knowledge transfer. Academy of Management Review, 3(1), 146-165.

Kipnis, D., Schmidt, S. M. and Wilkinson, I. (1980). Intraorganizational influence tactics: Explorations in getting one's way. Journal of Applied Psychology, 65(4), 440-452.

Kostova, T., Marano, V. and Tallman, S. (2016). Headquarters-subsidiary relationships in MNCs: Fifty years of evolving research. Journal of World Business, 51(1), 176-184.

Kostova, T. and Roth, K. (2003). Social capital in multinational corporations and a micro-macro model of its formation. Academy of Management Review, 28(2), 297-317.

Kristensen, P. H. and Zeitlin, J. (2005). Local players in global games. The strategic constitution of a multinational corporation. Oxford: Oxford University Press.

La Due Lake, R. and Huckfeldt, R. (1998). Social capital, social networks, and political participation. Political Psychology, 19(3): 567-584.

Labianca, G. and Brass, D. J. (2006). Exploring the social ledger: Negative relationships and negative asymmetry in social networks in organizations. Academy of Management Review, 31(3), 596614.

Levy, O. and Reiche, B. S. (2017). The politics of cultural capital: Social hierarchy and organizational architecture in the multinational corporation. Human Relations. https://doi.org/10.1177/0018726717729208

Liebeskind, J. P., Oliver, A. L., Zucker, L. and Brewer, M. (1996) Social networks, learning, and flexibility: Sourcing scientific knowledge in new biotechnology firms. Organization Science, 7(4), 428-443.

Lynch, S. E. and Mors, M. L. (2018). Strategy implementation and organizational change: How formal reorganization affects professional networks. Long Range Planning. https://doi.org/10.1016/j.lrp.2018.02.003

Menz, M., Kunisch, S. and Collis, D. J. (2015). The corporate headquarters in the contemporary corporation: Advancing a multimarket firm perspective. The Academy of Management Annals, 9(1), 633-714. 
Mintzberg, H. (1983). Power in and around organizations. Prentice Hall, Englewood Cliffs, NJ.

Molloy, E. \& Delany, E. (1998). Strategic Leadership of Multinational Subsidiaries. Dublin: MDL Management Consultants Ltd.

Monteiro, L.F., Arvidsson, N. and Birkinshaw, J. (2008). Knowledge flows within multinational corporations: Explaining subsidiary isolation and its performance implications. Organization Science, 19(1), 90-107

Morgan, G. and Kristensen, P. H. (2006). The contested space of multinationals: Varieties of institutionalism, varieties of capitalism. Human Relations, 59(11), 1467-1490.

Mudambi, R. and Navarra, P. (2004). Is knowledge power? Knowledge flows, subsidiary power and rent-seeking within MNCs. Journal of International Business Studies, 35(5), 385-406.

Mudambi, R., Pedersen, T. and Andersson, U. (2014). How subsidiaries gain power in multinational corporations. Journal of World Business, 9(1), 101-113.

Najafi-Tavani, Z., Giroud, A. and Andersson, U. (2014). The interplay of networking activities and internal knowledge actions for subsidiary influence within MNCs. Journal of World Business, 49(1), 122-131.

Narula, R. (2014). Exploring the paradox of competence-creating subsidiaries: balancing bandwidth and dispersion in MNEs. Long Range Planning, 47(1-2), 4-15.

O'Brien, D., Sharkey Scott, P., Andersson, U., Ambos, T. and Fu, N. (2018) The MicroFoundations of Subsidiary Initiatives: How Subsidiary-Manager Activities Unlock Entrepreneurship. Global Strategy Journal, DOI: 10.1002/gsj.1200

Pfeffer, J. (1978). The micro-politics of organizations. In Meyer, M. W. Environments and Organizations. Jossey-Bass, San Francisco, CA. 29-50.

Pla-Barber, J., Villar, C. and Madhok, A. (2017). Co-parenting through subsidiaries: A model of value creation in the multinational firm. Global Strategy Journal. DOI: 10.1002/gsj.1180

Thompson, J. A. (2005). Proactive personality and job performance: a social capital perspective. Journal of Applied Psychology, 90(5), 1011.

Tippmann, E., Scott, P.S., Reilly, M. and O’Brien, D. (2018). Subsidiary coopetition competence:

Navigating subsidiary evolution in the multinational corporation. Journal of World Business.

https://doi.org/10.1016/i.jwb.2018.02.006

Van Maanen, J., Sorensen, J. B. and Mitchell, T. R. (2007). The interplay between theory and methods. Academy of Management Review, 32(4), 1145-1154.

Welch, C., Marschan-Piekkari, R., Penttinen, H. and Tahvanainen, M. (2002). Corporate elites as informants in qualitative international business research. International Business Review, 11(5), 611628.

Welch, C., Piekkari, R., Plakoyiannaki, E. and Paavilainen-Mantymaki, E. (2011). Theorising from case studies: Towards a pluralist future for international business research. Journal of International Business Studies, 42(5), 740-762.

Winkler, I. (2010). Contemporary leadership theories: Enhancing the understanding of the complexity, subjectivity and dynamic of leadership. Springer Science \& Business Media.

Yamin, M. and Andersson, U. (2011). Subsidiary importance in the MNC: What role does internal embeddedness play?. International Business Review, 20(2), 151-162.

Yin, R. K. (2009). Case study research: Design and methods. 4th ed. United States: Library of Congress Cataloguing-in-Publication Data.

Zettler, I. and Lang, J. W. (2015). Employees' Political Skill and Job Performance: An Inverted U-Shaped Relation?. Applied Psychology, 64(3): 541-577. 
Table 1: Interviewee participants




Table 2: Case descriptions

\begin{tabular}{|c|c|c|c|c|c|c|c|}
\hline CASES & Estd. & $\begin{array}{l}\text { Subsidiaries } \\
\text { Globally }\end{array}$ & $\begin{array}{c}\text { Employees } \\
\text { Globally }\end{array}$ & $\begin{array}{l}\text { Est. in } \\
\text { Ireland }\end{array}$ & $\begin{array}{c}\text { Employees } \\
\text { in Irish } \\
\text { Subsidiary }\end{array}$ & $\begin{array}{c}\text { Irish } \\
\text { Subsidiary } \\
\text { 'Role' }\end{array}$ & $\begin{array}{c}\text { Functional } \\
\text { Expertise in } \\
\text { Irish } \\
\text { Subsidiary } \\
\end{array}$ \\
\hline HEALTHCO & $1920 \mathrm{~s}$ & 4 & 3,400 & $1970 \mathrm{~s}$ & 450 & $\begin{array}{l}\text { COE for } \\
\text { Catheters }\end{array}$ & $\begin{array}{c}\text { Manufacturing, } \\
\text { R\&D } \\
\text { Marketing }\end{array}$ \\
\hline MEDCO & $1940 \mathrm{~s}$ & 250 & 45,000 & $1990 \mathrm{~s}$ & 2,500 & $\begin{array}{l}\text { COE for } \\
\text { Catheters }\end{array}$ & $\begin{array}{c}\text { Manufacturing, } \\
\text { R\&D }\end{array}$ \\
\hline CHEMCO & $1980 \mathrm{~s}$ & 14 & 2,700 & $1990 \mathrm{~s}$ & 440 & $\begin{array}{c}\text { COE for } \\
\text { Guide-Wires }\end{array}$ & $\begin{array}{l}\text { Manufacturing, } \\
\text { R\&D, } \\
\text { Shared-services }\end{array}$ \\
\hline PHARMCO & $2000 \mathrm{~s}$ & 350 & 43,000 & $2000 \mathrm{~s}$ & 400 & $\begin{array}{c}\text { Capital } \\
\text { Equipment } \\
\text { Manufacture }\end{array}$ & Manufacturing \\
\hline VASCA & $1890 \mathrm{~s}$ & 39 & 74,000 & $2000 \mathrm{~s}$ & 600 & $\begin{array}{l}\text { COE for } \\
\text { Catheters }\end{array}$ & $\begin{array}{l}\text { R\&D, Product } \\
\text { Development }\end{array}$ \\
\hline SINCO & $1970 \mathrm{~s}$ & 26 & 25,000 & $1990 \mathrm{~s}$ & 3,000 & $\begin{array}{c}\text { International } \\
\text { Product } \\
\text { Develop- } \\
\text { ment Centre }\end{array}$ & $\begin{array}{c}\text { Manufacturing, } \\
\text { R\&D, Product } \\
\text { Development }\end{array}$ \\
\hline
\end{tabular}

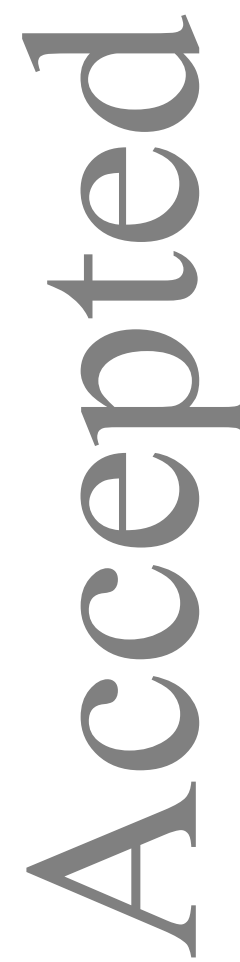

This article is protected by copyright. All rights reserved. 


\section{Representative Quotations}

"Making sure that you are in touch with the Directors and VPs in corporate so that they know you and see you so often that they lmost regard you as not being remote from them and there was a few of us that were constantly orer there anjwary so we tended to go around and talk to as many people as you could and let them lnow you were there" (Global Marketing $\mathrm{Kanag}$ HEALTHCO)

'You got to get over there, it is invaluable, plus having them here also... it is about taking the time to get to know the people, asking them what they do..." (Engineering Manager PHARMCO).

"it is incumbent on us that we get up and go there rather than waiting to be asked, so we are trying to find out what is going on around the table there" (R\&D Manager CHEMCO).

"I do not think anybody in HQ plots out the growth of [the Irish subsidiary], that is the subsidiary's responsibility and that is only fair..." (Senior R\&D Manager 1 MEDCO)

"If I was to come to the U.S. for two days work I would purposely stay for two more days just talking to people and involving people in what we were doing" (VP HEALTHCO).

"We hired someone a year ago and he has gone on to take a Director of an R\&D position in California. We hired him and it was a knock on position that was created as part of my move and then when that position came up he moved into it in California. In 3 or 4 years' time if people are trying to decide where R\&D can be done he will be able to recommend here" (R\&D Manager PHARMCO).

" $[\mathrm{CHQ}]$ acquired a company that makes products similar to ours, a decision will be made on that location, I think I am well ocationed, so I have been making sure that my boss understands that if there is a consideration for where to put that particular product" (Plant Manager PHARMCO).

"It is the flexibility of the people, we have had a lot of challenges, and we have always been flexible and willing to adjust to make the changes needed to be successful" (R\&D Manager PHARMCO).

"There has been a change in management in the US...we recognize that that is an important change" (VP Director of Manufacturing MEDCO).

"... If I was to say one thing I think it is the can do attitude and flexibility, I think that is Ireland's oil. A lot of people will say that too, for us we have seen that work bigtime" (VP CHEMCO).

"We are not going to change how that works so we have to be the ones who adapt and change... you are trying to change an ingrained culture of centuries so that is built into the way they [CHQ] work" (VP International Finance CHEMCO).

"The subsidiary] has always had Irish plant managers, we are biased in terms of Ireland is doing okay and we are doing okay. The problem with that is if we have people moving for two years with little loyalty to it and are focusing on their own career progression solely then that will be a very difficult place to be in the next 5-10 years" (Plant Manager HEALTHCO).

"At the start it was a decision that [the CEO] made, I was taken back and disappointed by that decision [to send an expatriate to manage the subsidiary R\&D] (R\&D Manager CHEMCO)

"The other thing that did not help us was we had major change in personnel that were not there for the initiation of the project so they did not feel they had any personal investment in it" (Plant Manager PHARMCO).

"I think we have been criticized in the past for overdoing this" (VP Director of Manufacturing MEDCO).

\section{First Order}

Codes

Second

Order Codes

- Increasing formal and informal social engagement

- Scheduling visits to and from corporate HQ

- Not waiting for

corporate HQ to act
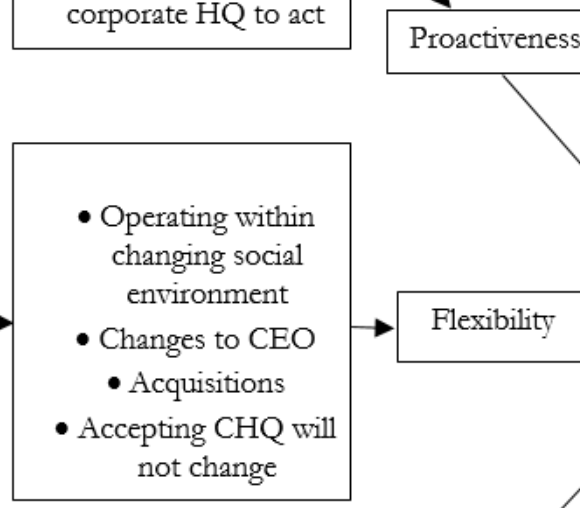

Aggregate

Themes

- Bias toward local managers

- Maintaining social

balance

- Ingratiation

This article is protected by copyright. All rights reserved. 
"Projects tend to be very complex and long so execution is a key part of wining repeat business" (MD SINCO)

"We look at the year ahead, we have five key projects we want to go after, and our key is to deliver on them" (NPD Manager CHEMCO).

"What we should be targeting is that if there is a new technology to be developed then we should be developing it here, we need to be targeting the newer ends of technology" (VP International Finance CHEMCO).

"One of the things we know he is going to look for is a talent review. This is something he is hot on, so we are looking at how we are managing talent and what is our processes," (Senior HR Manager MEDCO).

"We have a new CEO ... for the last six months he has been driving an initiative around overall cost saving. So we are ahead of the game" (NPD Manager MEDCO).

"If there is an exciting topic we would do a couple of slides on it in the presentation, just to give them [CHQ] a bit more comfort. Getting validation or positive feedback from clinicians is also good before we go into these meetings. Being able to communicate that is very important and they are aware of it" (Senior R\&D Manager VASCA).

"...you cannot manage them if results are not good but if they are good then its making sure that they are acknowledged and when its being acknowledged then you can reinforce it" (Plant Manager HEALTHCO).

"You are always trying to show yourself in the best light as possible, by saying look at what we have achieved in this year and we would not be shy in putting it out there" (VP International Finance CHEMCO).

"We highlight anything internally that shows we are progressing and developing" (Global Marketing Manager HEALTHCO).

"Everything you do you are really trying to market the site to try and make sure you are creating the right impression within the corporation" (Senior Manufacturing Director MEDCO).

"We go out of our way to help them understand the capabilities we have here and sell to them what we can do" (Director of Project Management SINCO).

"It only takes something small for it all to come crumbling down. We have been on this project now for a year and a half and anytime there is a minor screw up at all there is pandemonium, more with the senior guys here because it is all about 'well how is this going to play out at corporate level"' (Process Development Manager SINCO).

"When we did tell them they reacted very badly to it, they felt we had exceeded our remit and maybe given away some company secrets, gone behind their backs and not told them, the whole issue of trust and confidentiality, it was a dark time" (Strategy Director HEALTHCO).

"We got involved in other politics along the way when things were getting a bit tough. When we were running into problems, one or two people from the team were asked to sit in on projects and help [CHQ] with certain aspects" (R\&D Manager VASCA).

"When issues come up you have got to be willing to move really quickly to fix them, you have got to jump on it and you have got to be seen to jump on it" (R\&D Manager PHARMCO).

"It may not be good for the plant but we owe it to everyone to publicize this and recognize the fact that we are not good in efficiency and that we need to improve and here are all the things that we are going to do to improve. This is what we are going to do, this is the time frame, this is how we are doing it" (VP HEALTHCO).

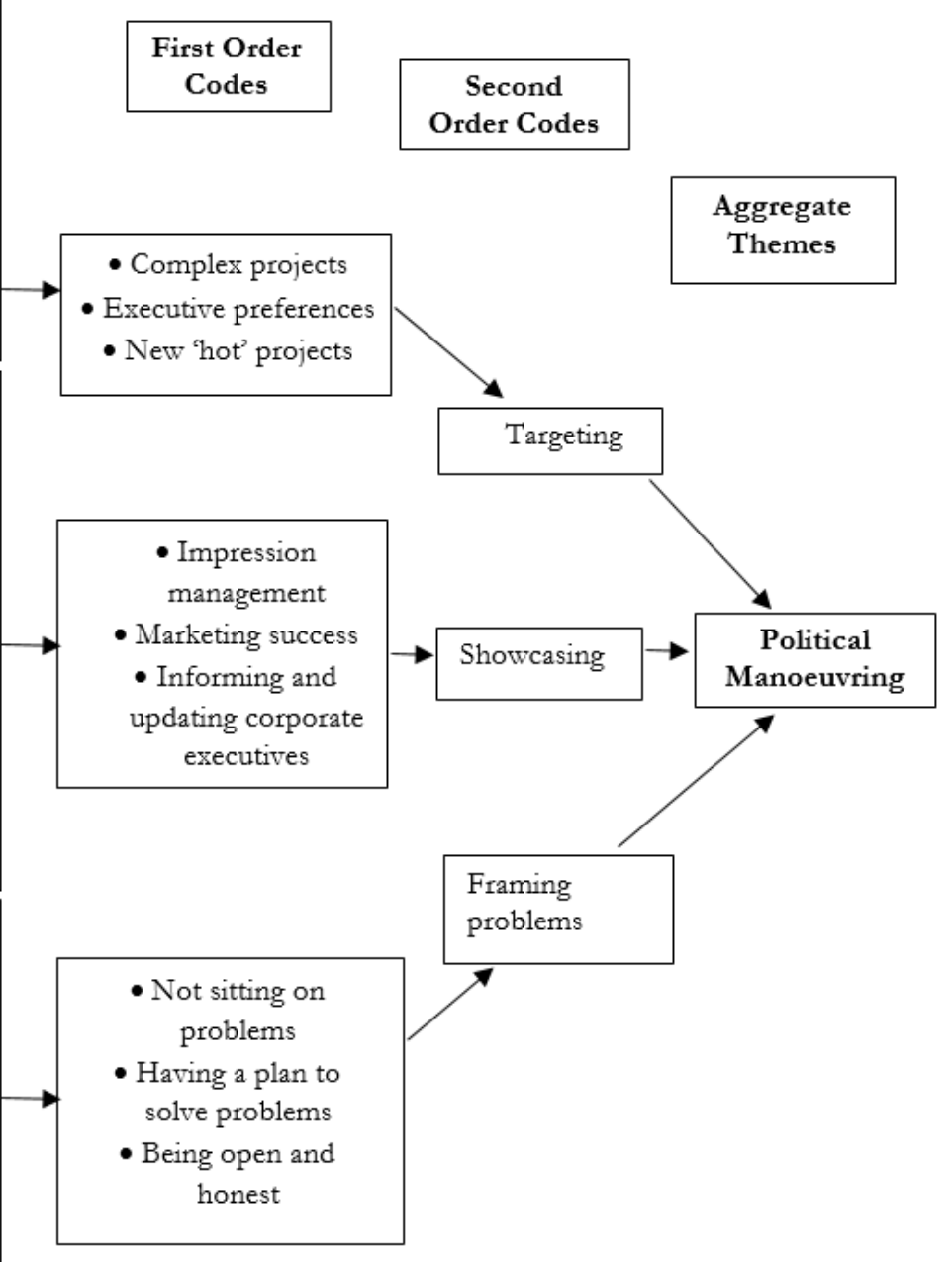

This article is protected by copyright. All rights reserved. 


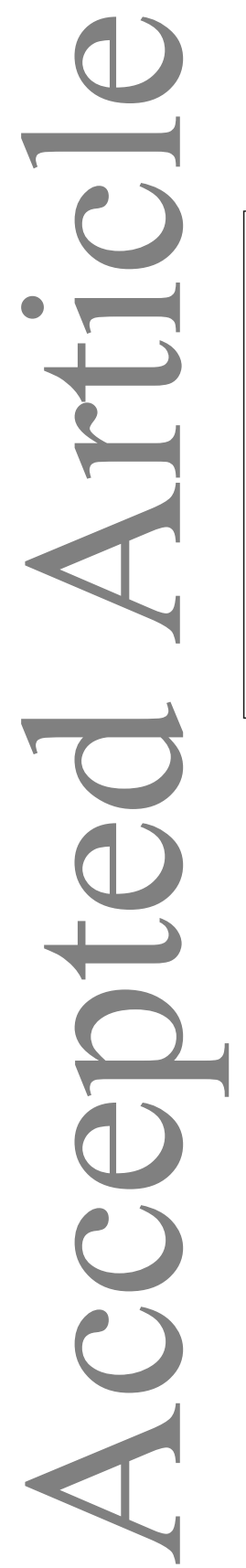

\section{Representative Quotations}

"We have had to change significantly, to reposition ourselves at the high end so a lot will be moving out and moving in... it has allowed me to position [the subsidiary] to continue to have an equal role and evolve and change" (VP MEDCO).

"Trying to make sure we have free and available space or if there is a higher value product that can be moved in, is there something of lower value that can be moved out" (Plant Manager PHARMCO).

"Realising at some point that the product life cycle is going to change to become more cost driven, and when it does you should look to off load those and replace them with the next technology" (MD VASCA)

"We got a situation where we were under pressure with space, in that we may not have enough, even if we get rid of the old stuff and bring in the new stuff" (Plant Manager HEALTHCO).

"What has happened primarily over the years is that we have moved products out of here and moved other products in" (Manufacturing Engineering Manager MEDCO).

"I am looking after expanding some subsidiaries and closing down others and rationalizing" (Strategy Director HEALTHCO).

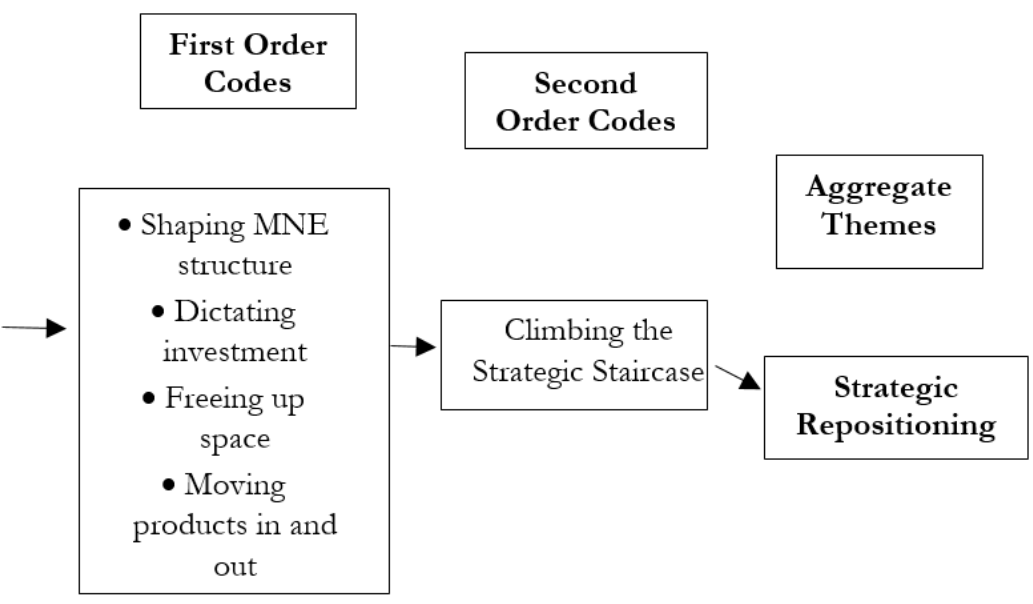

Figure 1: Data Structure

This article is protected by copyright. All rights reserved. 


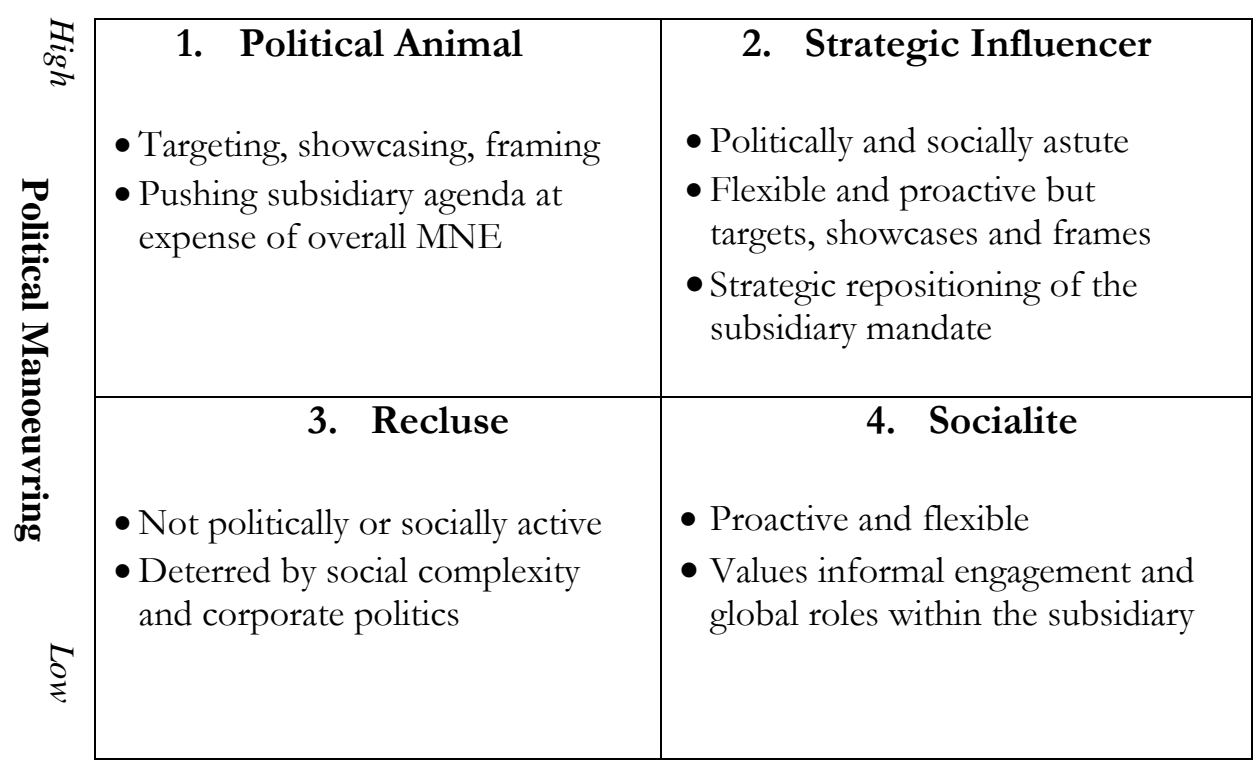

Figure 2: Subsidiary actor influence roles 